UDC 339.9:330.32

\title{
The impact of the Turn to the East Policy on foreign direct investment in the Russian Far East
}

\author{
Han-Sol Lee \\ Peoples' Friendship University of Russia (RUDN University) \\ 6 Miklukho-Maklaya St., Moscow, 117198, Russian Federation
}

\begin{abstract}
This study aims to measure the effectiveness of Russia's Turn to the East Policy, addressed by the federal government in 2012, on the economic development of the underdeveloped Far Eastern regions, in terms of foreign direct investment (FDI) inflows data. To do so, this paper analyzed the results of the representative policy mechanisms - designed to promote the Far Eastern investments - of the Turn to the East Policy, comprised of the Eastern Economic Forum (EEC), Advanced Special Economic Zones (ASEZs), and Vladivostok Free Ports (VFPs), based on the secondary data from the governmental organizations. From the study, in spite of the previous contentions on those policy mechanisms amongst policymakers, we elucidate the incremental growing FDI - majorly contributed by the East Asian countries: China, Japan, and South Korea - propensity in the Far East. The three Eastern Asian countries promote investments in the Russian Far East for different eco-political purposes. And it further analyzed that for Russia, despite the remarkable magnitude of Chinese and Japanese FDI compared to South Korea, South Korea is still the most attractive partner, in terms of lack of threats: The Chinese expansionism, and the Kuril Island dispute with Japan.
\end{abstract}

Keywords: Russia's Turn to the East Policy; Russia - East Asia Economic Cooperation; Eurasian economy; Asia-Pacific economy; foreign direct investment

\section{Introduction}

In 2012, the Russian Federation formalized the Turn to the East Policy by announcing "Measures to Implement the Russian Federation Foreign Policy". The main objective of the policy is developing the backward Far Eastern and Siberian regions by cooperating with Asia-Pacific countries. The Russia's continuous trends of the low economic growth, since the financial crisis in 2014, caused by the Western sanctions and the limitations on the previous quantitative economic growth model, motivated the country to search for the new economic growth engine besides resource industries by cooperating with the Eastern Asian countries, for instance, China, Japan, and South Korea, which achieved the remarkable economic growth. In accordance with the policy, the federal government implemented the policy mechanisms to develop the Far Eastern economy by attracting 
investments: Eastern Economic Forum (EEC), Advanced Special Economic Zones (ASEZs), Vladivostok Free Ports (VFPs), and Far Eastern Hectare (FEH). In this study, we investigate the impact of those policies on the economy of the Russian Far East particularly in terms of foreign direct investment (FDI) inflows based on the secondary data from the Central Bank of Russian Federation, Consulate General of the Republic of Korea in Vladivostok, Far East Development Corporation (FEDC), EEC, and FEH.

\section{Literature review}

Amongst all research topics on FDI, analyzing the determinant factors of FDI in emerging markets, where in spite of the fast-growing economy, investors should still embrace high risks of unpredictability, instability, and turbulence in recipient countries, was the major issue. A substantial number of previous studies explored the determinant factors of BRICS countries. Those studies are in line with given that no other than but economic factors are the most significant on FDI inflows in BRICS countries as the most investors in those countries highly seeks for market opportunities. On the empirical study on BRICS and MINT countries showed that market size, infrastructure availability, and trade openness are significant factors, while natural resources availability and institutional quality are insignificant factors in attracting FDI (Asongu, Akpan, Isihak, 2018). Other researchers also stated that due to the high attractiveness of markets - the wide domestic market, cheap labor, the wealth of natural resources - the corruption level is insignificant on FDI inflows (Gasanova, Medvedev, Komotskiy, 2017). In the study by Masron, Naseem and Wahab proved that Institutional Quality (IQ), the non-economic factor would mere but not must improve FDI in BRICS countries (Masron, Naseem, Wahab, 2018).

On the other hand, some studies devoted to analyzing the Russian FDI as a single subject. In the study on regional level analysis of the Russia, (Mariev, Drapkin, Chukavina, Heiko, 2016) stated that the gross domestic product of the investor's country, the gross domestic product per capita in the recipient region, the distance from the investor to Moscow, the openness of the region, the economic situation in the region, the innovative capacity of the region, and the foreign direct investment of the previous period significantly determine the FDI in the Russia but the distance from the recipient region to Moscow matters in the western part of Russia only while does not in the eastern part (remote regions). Besides, N. Zakharov found the common negative relationship between the corruption measured by the bribery taking, the freedom of journalism, and the investments, in spite of the different influence depending on company types: bigger for private companies while smaller for public companies (Zakharov, 2019).

\section{The EEC:}

\section{a platform for attracting the investments in the Russian Far East}

The Russian Far Eastern development entails enormous financial supports. Thereby, the Eastern Economic Forum, the international platform attracting investments in the Far East, was established by Decree No. 250 of President Vladimir 
Putin in 2015. Since 2015, the forum has been held every year in Vladivostok. The main objectives of the forum are prospecting economic potentials of the Far East, providing investment opportunities in Advanced Special Economic Zones and Vladivostok Free Ports, and building economic, political, and cultural ties with Asia Pacific countries. The summits of Russia, South Korea, China, Japan, and Mongolia have been attended the forum and addressed keynotes. Given that forum is one of the three major economic forums hosted by the federal government along with Saint Petersburg International Economic Forum and Sochi Economic Forum, and thus by considering the importance on it, the president Putin attended the form in every year (Table 1).

The status of national representative attendees in the EEC by each year

\begin{tabular}{cc}
\hline Year & Major summit attendees \\
\hline 2015 & President Vladimir Putin (Russia) \\
\hline 2016 & President Vladimir Putin (Russia), President Park Geun-hye (South Korea), \\
Prime Minister Shinzo Abe (Japan)
\end{tabular}

Source: composed by author based on the yearly EEC result reports.

The key results of Eastern Economic Forum in each year

\begin{tabular}{|c|c|c|}
\hline Year & MOU (number) & The number of participants \\
\hline 2015 & 1.8 trillion rubles (109) & $\begin{array}{l}\text { - 2,500 participants from } 32 \text { countries } \\
\text { - } 550 \text { journalists }\end{array}$ \\
\hline 2016 & 1.63 trillion rubles (201) & $\begin{array}{l}\text { - 3,500 participants from } 56 \text { countries } \\
\text { - 1,100 journalists } \\
\text { - } 246 \text { participants from Japan, } 227 \text { participants from China, } \\
128 \text { participants from South Korea } \\
\text { - } 207 \text { participants from Russian enterprises, } 94 \text { participants } \\
\text { from foreign enterprises }\end{array}$ \\
\hline 2017 & 2.496 trillion rubles (217) & $\begin{array}{l}\text { - } 6,000 \text { participants from } 60 \text { countries } \\
\text { - 1,094 of journalists } \\
\text { - } 240 \text { participants from Russian enterprises, } 103 \text { participants } \\
\text { from foreign enterprises }\end{array}$ \\
\hline 2018 & 3.108 trillion rubes $(220)$ & $\begin{array}{l}\text { - 6,000 participants from } 60 \text { countries } \\
\text { - 1,357 journalists } \\
\text { - 1,096 participants from China, } 570 \text { participants from Japan, } \\
335 \text { participants from South Korea, } 12 \text { participants from North } \\
\text { Korea } \\
\text { - } 383 \text { participants from Russian enterprises, } 340 \text { participants } \\
\text { from foreign enterprises }\end{array}$ \\
\hline
\end{tabular}

Source: composed by author based on the yearly EEC result reports.

The number of participants to EEC continuously increased in each year, and, in the latest forum, approximately 6,000 participants attended from 60 countries. 
The most significant number of attendees from three East Asian countries: China, Japan, and South Korea. Besides, in 2018, 12 attendees from North Korea participated in the forum for the first time as inter-North-South Korean relations eased. The number of participants of both national and foreign enterprises increased. While, in 2016, the participants of foreign enterprises were less than half of national enterprises, the number of the participants of the national and foreign enterprise became almost equal in 2018. In terms of Memorandum of Understanding (MOU), the total amount of 9.043 trillion rubles were concluded for the four years during the forums (Table 2).

\section{The overview of FDI inflows in the ASEZs and VFPs in the Russian Far East}

As a means to promoting investments, 18 areas in the Far East were designated as ASEZ based on the Federal Law No. 473-FL from the effectuation of the law from 2015 to 2018. Besides, in accordance with the Federal Law No. 212, 16 districts in Vladivostok and 6 districts in Khabarovsk, Sakhalin, Chukotka, Kamchatka were designated as VFP from the effectuation of the law from 2015 to 2018. The companies entering in those areas and districts could benefit from tax breaks and simplified administrations. By connecting ASEZs - production bases, and FPVs - a logistic-hub, it is expected to create synergy effects (Far East Development Corporation, 2018a, 2018b). The Table 3 shows that since 2012, FDI balance of payments (BoP) in the Far East has been increasing year on year, only excluding the year 2017. From 2012 to 2017 , the average growth rate is $95 \%$. In 2016, for the first time, the FDI BoP was over \$ 10 billion. The FDI percentage in the Far East of the total has been increased compared with in 2012 and the economic importance of the regions has been grown. In 2017, the FDI BoP in the FarEastern Federal District was the third out of the eight districts. The average for the six years is $6.2 \%$ but, during the recent three years, it is above than that.

Table 3

The FDI BoP in the Russian Far East (millions US dollars)

\begin{tabular}{ccccccc}
\hline Year & $\mathbf{2 0 1 2}$ & $\mathbf{2 0 1 3}$ & $\mathbf{2 0 1 4}$ & $\mathbf{2 0 1 5}$ & $\mathbf{2 0 1 6}$ & $\mathbf{2 0 1 7}$ \\
\hline FDI & 563 & 1,392 & 5,055 & 7,077 & 10,385 & 8,157 \\
$\begin{array}{c}\text { The percentage of } \\
\text { the total (\%) }\end{array}$ & $4.7 \%$ & $4.0 \%$ & $5.6 \%$ & $7.9 \%$ & $8.4 \%$ & $6.8 \%$ \\
\hline
\end{tabular}

Source: The Central Bank of the Russian Federation (2018).

According to the report published by the Consulate General of the Republic of Korea in Vladivostok, Russia, from the effectuation the federal law to 31 December, 2017, 212 companies, expected to invest 2.181 trillion rubles, completed the procedures to move in the ASEZ. The number of foreign enterprises is 22, expected to invest 164.5 billion rubles. 15 enterprises are from East Asian countries: China, South Korea, and Japan. China, whose investment is $80.9 \%$ of the total, is the largest investor (Table 4). 
On the other hand, 432 companies, expected to invest 365 billion rubles, concluded an agreement on FPV by December 31, 2017. 26 foreign enterprises, estimated to invest 75 billion rubles, entered in the districts. 21 enterprises are invested by East Asian countries: China (12), South Korea (5), and Japan (4). Japanthe largest investor - invested 62,312 million rubles, $83.3 \%$ of the total (Table 5).

The expected FDI in ASEZ

Table 4 (hundred million Russian rubles)

\begin{tabular}{ccc}
\hline Country & The number of enterprises & Expected investments \\
\hline South Korea & 3 & 13.4 \\
China & 9 & 1316.1 \\
Japan & 3 & 28.6 \\
Australia & 2 & 106.4 \\
Vietnam & 1 & 160 \\
Singapore & 1 & 18.7 \\
Israel & 1 & 1.1 \\
Lithuania & 1 & 0.77 \\
Netherlands & 1 & 0.462 \\
Total & 22 & 1645.532 \\
\hline
\end{tabular}

Source: The Consulate General of the Republic of Korea in Vladivostok, Russia (2018).

\section{The expected FDI in FPV}

(million Russian rubles)

\begin{tabular}{ccc}
\hline Country & The number of enterprises & Expected investments \\
\hline South Korea & 5 & 3,091 \\
China & 12 & $8,374.10$ \\
Japan & 4 & 62312 \\
Singapore & 1 & 174.9 \\
UK & 1 & 140.3 \\
UK, Mexico, USA & 1 & 233.5 \\
India & 1 & 496.6 \\
Total & 26 & 74,822 \\
\hline
\end{tabular}

Source: The Consulate General of the Republic of Korea in Vladivostok, Russia (2018).

Especially, recently, three East Asian countries - China, Japan, and South Korea - in earnest initiated FDI projects in the Russian Far East with political and economic purposes in their mind. In 2013, Chinese President Xi Jinping publicized the new political initiative, One Belt One Road (OBOR), designed to secure a stable energy and resource transportation by jointly advocating the safety of ener- 
gy pipelines as a means to enhancing the interconnection of energy infrastructure and expanding and improving power networks across national borders between countries in the cooperation. And, China stated that Russia, the resource-abundant country, as one of the key countries for energy cooperation. In December 2015, the bilateral economic cooperation between the two countries was promoted in earnest by signing on a memorandum on China-Russia economic cooperation in the Russian Far East (Yang, Lee, Im, 2017).

In the meantime, since 2016, Japan, one of the countries which have been involved in Western sanctions, has been taken the decisive action on the bilateral economic cooperation with an intent to return to the four islands of the Kuril peninsula. Japan dispatched more delegations (Japan - 246; China - 227) than China to the second EEF, and it was the largest among the 56 participating countries.

Besides, the heavy economic dependency on USA and China and the improvement of the inter-Korea's relations spurred South Korea to initiate the New Northern Policy aiming to expand economic cooperation with the Northern countries, for instance, Russia, Ukraine, Belarus, Central Asian countries, and the northeast region of China, to diversify economic partners and create new economic opportunities.

However, the economic cooperation with China and Japan has some risks for Russia; historically, the Russian Far East has been threatened by the Chinese expansionism, which perennially requiring Russia to assert the ownership of the regions (Gabue, Spivak, 2016; Blakkisrud, 2018); and the Japanese investments heavily rest in the premises of returning the four islands of the Kuril peninsula. On the contrary, given that by cooperating with Russia, South Korea could leverage Russia for the inter-Korea-relations and also create new economic values, exceptionally, South Korea does not hold any risk-factors or threats to Russia.

In addition, to increase inflows of populations in the Far East, the federal government enacted the Federal Law No. 119-FL on the Far Eastern Hectare in 2016. According to the law, every citizen of the Russian Federation, migrating to the Far East, is given the right to receive a free land plot of up to 1 hectare. The new law is expected to resolve the demographic problems of the low population density and persistent outflows of the population in the Far East and to contribute on increasing attractiveness for investors of the regions. ${ }^{1}$

\section{Conclusion}

To promote the economic growth in the Far East in accordance with Russia's 2012 Turn to the East Policy, the federal government consecutively enforced special policies - EEC, ASEZ, and VPF - to attract investments in the regions by creating favorable business environments. In this study, we examined the effectiveness of these policies based on the yearly EEC round-up reports from 2015 to 2018 and the FDI data in ASEZ and VPF by 2017. From the study, we draw the following significant conclusions.

Firstly, we found that all three separate policies interactively functioned under the unified mechanism of the Turn to East Policy and positively contributed to

\footnotetext{
${ }^{1}$ Ministry for the Development of the Russian Far East. (n.d.). 'Far Eastern Hectare'. URL: https:// eng.minvr.ru/activity/razvitie-msp-i-konkurentsii/dalnevostochnyy-gektar/ (accessed: 10 December 2018).
} 
attracting the investments in the Russian Far East. EEC, an investment platform, provides the information to potential investors on lucrative and promising business opportunities in the Russian Far East under the government's guarantee, while ASEZs, production bases, and VPFs, a logistic hub, by offering benefits, for instance, a tax break, and simplified administrations, contributes to the execution of MOUs concluded in the EEC.

Secondly, Russia's Turn to the East Policy mechanisms are effectively implementing, as considering that from 2012 to 2017, the Far East's nominal FDI and its percentage had been on a rising trend in general. In 2017, the Far Eastern Federal District was the third out of the eight federal districts in terms of the FDI BoP. Besides, given that the increasing number of the participants and concluded MOUs in the EEC in every year, this rising trend of FDI is expected to be continued in the future.

Thirdly, the investments of the three East Asian countries - China, South Korea, and Japan - in ASEZs and VFPs are remarkably greater than other foreign investors by following their own governmental policies on the economic cooperation with Russia. In ASEZs and VFPs, China and Japan, respectively, are expected to be the largest investors. However, given that historically, the Russian Far East has been threatened by the Chinese expansionism, while the Japanese economic cooperation is based on the resolution of the territorial dispute on the Kuril island. Thereby, Russia, for the economic cooperation with China and Japan, has to carry the risk of being a zero-sum game. On the contrary, in spite of the most sluggish South Korean investments in the Russian Far East compared to China and Japan, in terms of a strategy, South Korea is the only partner which can lead the economic cooperation to a positive-sum game by leveraging the South Korea Russia economic cooperation for the inter-Korean relations.

Some demonstrated skepticism on the Turn to the East Policy. It could be argued that what has been achieved over the past years on the economic development of the Russian Far East is unremarkable. However, this study manifests the incremental but positive trends in the Russian Far East in terms of the investments. In this manner, to compass the intended goals on the economy of the Russian Far East, the yielded small fruits by the policy needs to be seen with a longterm vision (Blakkisrud, 2018).

\section{References}

Asongu S., Akpan U.S., Isihak, S.R. (2018). Determinants of foreign direct investment in fastgrowing economies: evidence from the BRICS and MINT countries. Financial Innovation, 4(1), 26.

Blakkisrud H. (2017). An Asian Pivot Starts at Home: The Russian Far East in Russian Regional Policy. In Blakkisrud, H., Rowe, E. W. (Eds.), Russia's turn to the east: Domestic policymaking and regional cooperation (pp. 11-30). doi.org/10.1007/978-3-31969790-1_2

Far East Development Corporation. (2018a). ASEZ (Advanced Special Economic Zone). Retrieved from https://erdc.ru/en/about-tor/

Far East Development Corporation. (2018b). FPV (Free Port of Vladivostok). Retrieved from https://erdc.ru/en/about-spv/

Gabuev A., Spivak V. (2016). Should Russia Be Afraid of Chinese Plans in the Far East? Carnegie Moscow Center. Retrieved from https://carnegie.ru/commentary/63740 
Gasanova A., Medvedev A.N., Komotskiy E.I. (2017). The assessment of corruption impact on the inflow of foreign direct investment. AIP Conference Proceedings, 1836(1), 020011. AIP Publishing.

Mariev O.S., Drapkin I.M., Chukavina K.V., Rachinger Heiko. (2016). Determinants of FDI inflows: the case of Russian regions. Economika regiona [Economy of region], 12(4), $1244-1252$.

Masron T.A., Naseem N.A.M., Wahab E.A.A. (2018). Institutional Quality in Attracting Foreign Direct Investment to Small Countries. Malaysian Journal of Economic Studies, $55(2), 267-284$.

The Central Bank of Russian Federation. (2018). Inward Direct Investment in the Russian Federation by Region of Resident's Registration. Retrieved from www.cbr.ru/vfs/eng/ statistics/credit_statistics/direct_investment/dir-inv_reg-in_e.xlsx

The Consulate General of the Republic of Korea in Vladivostok, Russia. (2018). 2018 선도개발구역 및 블라디보스톡 자유항 제도 [2018 Leading Development Zone and Vladivostok Freeport System]. (In Korean.)

Yang E.S., Lee J.L., Im J.Y. (2017). 중국·일본의 러시아 극동지역 석유·가스 자원 활용 전략 [Strategies for Utilizing Oil and Gas Resources in the Russian Far East, China and Japan]. World Energy Market Insight, (17-18), 3-17. (In Korean.)

Zakharov N. (2019). Does corruption hinder investment? Evidence from Russian regions. European Journal of Political Economy, 56(C), 39-61. DOI: 10.1016/j.ejpoleco.2018.06.005

Article history:

Received: 02 March 2019

Revised: 07 April 2019

Accepted: 14 May 2019

\title{
For citation:
}

Lee H.-S. (2019). The impact of the Turn to the East Policy on foreign direct investment in the Russian Far East. RUDN Journal of Economics, 27(2), 366-374. http://dx.doi.org/ 10.22363/2313-2329-2019-27-2-366-374

\section{Bio note:}

Han-Sol Lee - PhD student, Peoples' Friendship University of Russia (RUDN University). E-mail: hanso1900217@gmail.com

\section{Влияние политики «Поворот на Восток»} на прямые иностранные инвестиции на Дальнем Востоке

\author{
Х.-С. Ли \\ Российский университет дружбы народов \\ Российская Федерация, 117198, Москва, ул. Миклухо-Маклая, 6
}

Целью исследования является оценка эффективности политики России «Поворот на Восток: развитие Сибири и Дальнего Востока в условиях усиления азиатского вектора внешней политики России», принятой федеральным правительством в 2012 году в 
рамках экономического развития слаборазвитых регионов Дальнего Востока, на основе данных о притоке прямых иностранных инвестиций (ПИИ). Для этого на базе вторичных данных правительственных организаций были проанализированы результаты работы наиболее характерных политических механизмов, разработанных для продвижения дальневосточных инвестиций в рамках политики «Поворота на Восток», которые включают Восточный экономический форум (ВЭФ), Территорию опережающего развития (ТОР) и Свободный порт Владивосток (СПВ). Вопреки предыдущим спорам о вышеперечисленных политических механизмах среди представителей правительственных структур, настоящее исследование свидетельствует об увеличении ПИИ, основная доля которых приходится на страны Восточной Азии - Китай, Японию и Южную Корею, чье присутствие четко ощущается на Дальнем Востоке. Указанные страны Восточной Азии поощряют инвестиции в Дальний Восток России в различных экополитических целях. Кроме того, можно заключить, что для России, несмотря на крупные масштабы китайских и японских ПИИ по сравнению с корейскими, Южная Корея по-прежнему является наиболее привлекательным партнером, благодаря отсутствию геополитических опасностей, таких как китайский экспансионизм и спор о Курильских островах с Японией.

Ключевые слова: Россия в восточной политике; экономическое сотрудничество; Россия - Восточная Азия; евразийская экономика; экономика Азиатско-Тихоокеанского региона; прямые иностранные инвестиции

\section{История статьи:}

Дата поступления в редакцию: 02 марта 2019

Дата проверки: 07 апреля 2019

Дата принятия к печати: 14 мая 2019

\section{Для цитирования:}

Lee H.-S. The impact of the Turn to the East Policy on foreign direct investment in the Russian Far East (Влияние политики «Поворот на Восток» на прямые иностранные инвестиции на Дальнем Востоке) // Вестник Российского университета дружбы народов. Серия: Экономика. 2019. Т. 27. № 2. С. 366-374. http://dx.doi.org/10.22363/ 2313-2329-2019-27-2-366-374

\section{Сведения об авторе:}

Ли Хан-Сол- аспирант, Российский университет дружбы народов. E-mail: hanso1900217@, gmail.com 